\title{
PENERAPAN KEPPRES NOMOR 80 TAHUN 2003 DALAM PROSES PEMILIHAN PEMENANG TENDER PROYEK KONSTRUKSI DI SUMATERA BARAT
}

\author{
Martalius Peli ${ }^{* 1}$, Vivi Ariani ${ }^{2}$ \\ 1Dosen Program Studi Teknik Ekonomi Konstruksi, Fakultas Teknik Sipil dan \\ Perencanaan, Universitas Bung Hatta \\ 2 Dosen Program Studi Teknik Ekonomi Konstruksi, Fakultas Teknik Sipil dan \\ Perencanaan, Universitas Bung Hatta \\ *Korespondensi: viviariani@bunghatta.ac.id
}

\begin{abstract}
Tender is a competition system for selecting contractors who will carry out development activities. The mistake of the tender committee in choosing a contractor will cause losses to the project owner. To avoid that mistake, the tender committee must know the capabilities and quality of the contractor, so an assessment of the capabilities of the contractor (construction service) is needed. This research was conducted only for the tender process of physical work and the questionnaire was given to 50 contractor companies in West Sumatra to determine the weight of seven criteria of the most important assessment process in tender tenders in accordance with Presidential Decree No. 80 Republic of Indonesia year 2003 (Keputusan Presiden No. 80 tahun 2003). 50 questionnaires are distributed with result 43 returned questionnaires showed that the assessment criteria for implementation time had the highest percentege of $19 \%$ followed by work methods and experts with a percentege of $17 \%$ and subsequently company capital with a percentege of $16 \%$, and working capital received the fourth demand with a percentage of $11 \%$, while the company's experience and ranks last is equipment with a percentege of $10 \%$.
\end{abstract}

Keywords : Assessment Criteria, Tenders, Presidential Decree No. 80 Republic of Indonesia year 2003

\section{PENDAHULUAN}

Menurut Dipohusodo [1] Pelaksanaan proyek konstruksi biasanya melibatkan tiga pihak utama yaitu pemilik (owner), konsultan, dan pelaksana (kontraktor). Pemilik proyek menghendaki agar konstruksi bangunan yang dihasilkan sesuai dengan keinginanya. Sebelum proyek dilaksanakan, pemilik proyek harus membuat suatu perencanaan yang matang tentang pekerjaan yang akan dilakukan. Namun sering karena keterbatasan sumber daya atau keahlian yang tidak cukup tersedia di organisasinya, pemilik proyek membutuhkan jasa konsultan untuk perencanaan proyek dan kontraktor untuk melaksanakan proyek tersebut.

Pemilihan kontraktor dapat dilakukan dengan mengadakan suatu tender atau lelang.
Tender merupakan suatu sistem kompetisi untuk memilih kontraktor dan konsultan yang akan melaksanakan kegiatan pembangunan yang bertujuan agar terciptanya persaingan yang sehat antara peserta tender dalam mengajukan penawaran pekerjaan. Selain itu dengan adanya tender diharapkan mendapat pemenang yang benar-benar terbaik di bidangnya. Pemilik proyek biasa membentuk panitia tender (lelang) yang fungsi dan tugasnya untuk mengevaluasi masing-masing kontraktor sehingga didapatkan pemenang yang memenuhi syarat dengan kualitas dan kemampuan kerja yang bagus, serta memahami dan mengerti dengan pekerjaan yang akan dilaksanakan [2].

Biasanya pemenang tender adalah pihak yang menawarkan harga paling rendah diantara peserta tender lainnya. Sistim penilaian seperti 
ini merupakan kelemahan dalam proses dan evaluasi hasil tender, karena tidak ada acuan perhitungan nilai teknis lainnya sehingga terjadi ketidakadilan dalam menilai suatu calon rekanan, sementara calon rekanan tertentu diarahkan untuk menang. Kesalahan panitia tender dalam memilih kontraktor akan menimbulkan kerugian bagi pemilik proyek karena kurangnya pemahaman kontraktor akan pekerjaan yang dilaksanakannya, akan berpengaruh terhadap hasil pekerjaan misalnya hasil proyek yang tidak sesuai dengan keinginan pemilik proyek.

Oleh karena itu penulis tertarik untuk melakukan suatu studi bagaimana jika penentuan pemenang tender itu tidak saja dinilai dari harga penawaran tapi juga melalui penilaian terhadap persyaratan teknis lainnya seperti metode pelaksanaan, keahlian atau sumber daya manusianya, pengalaman perusahaan (track record), peralatan yang digunakan, dan waktu penyelesaian perusahaan itu sendiri di dalam dunia konstruksi.

\section{TINJAUAN PUSTAKA}

Proyek adalah suatu rangkaian dengan tujuan tertentu, yang dibatasi oleh waktu (awal-akhir) serta melibatkan banyak unsur (tenaga, uang dan material). Sedangkan pengertian proyek kontruksi adalah serangkaian kegiatan yang menghasilkan bangunan-bangunan kontruksi. [3]

Proyek-proyek kontruksi terus berkembang menjadi pekerjaan yang semakin komplek dan melibatkan berbagai pihak dengan tugas dan tanggung jawab yang berbeda. Pemilik proyek mempunyai tanggung jawab untuk membiayai proyek dari awal sampai akhir dari kegiatan proyek, konsultan bertugas untuk melakukan perencanaan dan pengawasan, sedangkan kontraktor bertugas untuk melaksanakan proyek tersebut.[1]

Proyek kontruksi sebenarnya sudah dimulai sejak timbulnya prakarsa dari pemilik untuk membangun, yang dalam proses selanjutnya melibatkan dan dipengaruhi oleh prilaku berbagai unsur seperti para konsultan, kontraktor dan termasuk pemiliknya sendiri. Secara garis hubungan antara ketiga unsur tersebut dapat digambarkan pada Gambar 1 [1].

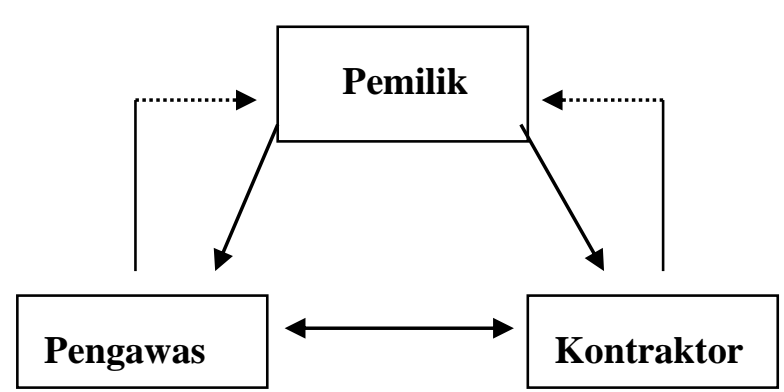

Keterangan :

Hubungan Kontrak =

Hubungan Koordinasi $=$

Gambar 1. Hubungan Antara Pemilik, Pengawas, dan Kontraktor

Untuk memenuhi kebutuhan pihak owner sebagai terjadi perkembangan yang menarik dalam cara konsultan dan kontraktor dalam memberikan pelayanan jasanya. Sejalan dengan perkembangan praktek-praktek kontruksi, tampaknya telah berlangsung sistem pelayanan jasa konsultan dalam proyek kontruksi terurai dan terpecah belah, hingga muncul konsultan perencana, konsultan manajemen kontruksi dan konsultan rekayasa nilai. Jasa lainya seperti konsultan sistem manejemen proyek, konsultan mekanikal dan elektrikal, konsultan pajak dan akuntansi, konsultan pemasaran. [4]

Dengan pertumbuhan proses dan praktek-praktek kontruksi, jasa kontruksi mempunyai peranan penting dan strategis mengingat jasa kontruksi menghasilkan produk akhir berupa bangunan atau bentuk fisik lainya, baik yang berupa prasarana maupun sarana yang berfungsi mendukung pertumbuhan dan perkembangan dalam berbagai bidang, baik di bidang ekonomi, sosial ataupun budaya untuk kemakmuran masyarakat. [5]

Prinsip-prinsip dasar pengadaan barang atau jasa dilingkungan instansi pemerintahan berdasarkan Keppres 80 tabun 2003 [2], meliputi :

a. Efisien

Berarti pengadaan barang atau jasa harus diusahakan dengan menggunakan dana dan daya yang terbatas untuk mencapai sasaran yang ditetapkan dalam waktu sesingkat-singkatnya dan dapat dipertanggungjawabkan. 
b. Efektif

Berarti pengadaan barang atau jasa harus sesuai dengan kebutuhan yang telah ditetapkan dan dapat memberikan manfaat yang sebesar-besarnya sesuai dengan sasaran yang ditetapkan.

c. Terbuka dan Bersaing

Berarti pengadaan barang atau jasa harus terbuka bagi penyedia barang atau jasa yang memenuhi persyaratan dan dilakukan melalui persaingan yang sehat diantara penyedia barang antara jasa yang setara dan memenuhi syarat atau kriteria tertentu berdasarkan ketentuan dan prosedur yang jelas dan transparan.

d. Transparan

Berarti semua ketentuan dan informasi mengenai pengadaan barang atau jasa, termasuk syarat teknis administrasi pengadaan, tata cara evaluasi, penetapan calon penyedia barang atau jasa, sifatnya terbuka bagi peserta penyedia barang atau jasa yang berminat serta bagi masyarakat luas pada umumnya

e. Adil

Berarti memberikan perlakuan yang sama bagi semua calon penyedia barang atau jasa dan tidak mengarah untuk memberi keuntungan kepada pihak tertentu, dengan cara dan atau alasan apapun.

f. Akuntabel

Berarti harus mencapai sasaran fisik, keuangan maupun manfaat bagi kelancaran pelaksanaan tugas umum pemerintahan dan pelayanan masyarakat sesuai dengan prinsip-prinsip serta ketentuan yang berlaku dalam pengadaan barang atau jasa.

Berdasarkan Keppres 80 tahun 2003 [2],

kualifikasi penyedia barang atau jasa adalah :

1. Penyedia barang atau jasa yang terkait dan berpartisipasi dalam pengadaan barang atau jasa harus memenuhi persyaratan antara lain :

a) Memenuhi ketentuan peraturan perundang-undangan untuk menjalankan usaha atau kegiatan sebagai penyedia barang atau jasa.

b) Memiliki keahlian pengalaman, kemampuan teknis dan manajerial untuk menyediakan barang dan jasa.

c) Tidak dalam pengawasan peradilan, tidak pailit, kegiatan usahanya sedang tidak dihentikan, dan direksi tidak bertindak untuk dan atas nama perusahaan tidak sedang dalam menjalankan sanksi pidana.

d) Memiliki sumber daya manusia, modal peralatan dan fasilitas lain yang diperlukan dalam pengadaan barang dan jasa.

e) Secara hukum mempunyai kapasitas menandatangani kontrak pengadaan.

f) Sebagai wajib pajak sudah memenuhi kewajiban perpajakan tahun terakhir, dibuktikan dengan melampirkan bukti foto copy bukti tanda terima penyampaian surat pajak tahunan (SPT) pajak penghasilan (PPh) tahun terakhir, foto copy surat setoran pajak (SSP) PPh pasal 29.

g) Tidak membuat pernyataan yang tidak benar tentang kualifikasi, klasifikasi dan sertifikasi yang memilikinya.

h) Tidak masuk daftar hitam.

i) Memiliki alamat tetap dan jelas dapat dijangkau pos.

2. Khusus untuk kualifikasi penyedia jasa konstruksi, maka persyaratan yang dipenuhi tenaga ahli yang akan ditugaskan dalam melaksanakan pekerjaan jasa konsultasi adalah :

a) Memiliki nomor pokok wajib pajak (NPWP) dan bukti penyelesaian kewajiban pajak bagi wajib pajak.

b) Lulusan perguruan tinggi negeri atau perguruan tinggi swasta yang telah lulus ujian negara atau yang telah diakreditasi dibuktikan dengan foto copy ijazah.

c) Memiliki pengalaman dibidangnya sesuai dengan referensi pengalaman kerja yang dituangkan dalam daftar riwayat hidup yang harus ditulis dengan teliti dan benar, ditandatangani oleh yang bersangkutan dan diketahui oleh pimpinan perusahaan.

d) Tenaga ahli lembaga swadaya masyarakat memiliki pengalaman dan keahlian di bidangnya yang dituangkan dalam daftar riwayat hidup yang ditetapkan oleh kepala kantor, satuan kerja, pimpinan, pejabat atau ditunjuk.

Berdasarkan Keppres 80 tahun 2003 [2], sistem evaluasi penawaran pengadaan jasa konsultasi dibagi atas :

a. Sistem Evaluasi Kualitas

b. Sistem Evaluasi kualitas dan Biaya

c. Sistem Evaluasi Pagu Anggaran

d. Sistem Evaluasi Biaya Terendah

e. Sistem evaluasi Penunjukan Langsung

Untuk lebih jelasnya mengenai sistim evaluasi penwaran, dapat dilihat sebagai 
berikut :

1. Tender Sebagai Pelaksanaan Jasa
Kontruksi
Kegiatan tender atau pelelangan merupakan langkah awal dari kegiatan kontruksi.Tender merupakan suatu sistim kompetisi untuk mengadakan atau memilih kontraktor yang akan melaksanakan pekerjaan pembangunan, dan memilih konsultan sebagai wakil pemilik (owner) didalam proyek, dengan mengajukan penawaran tertulis tentang besarnya biaya dan limit waktu yang dibutuhkan. [2]

Tender dalam suatu kegiatan kontruksi bertujuan agar terciptanya persaingan yang sehat antara rekanan atau peserta tender dalam mengajukan penawaran pekerjaan. Melalui proses pelelangan, pemilik (owner) dapat menentukan jasa konsultan dan kontraktor yang tepat untuk melaksanakan pekerjaan sesuai dengan keinginannya, agar dalam pelaksanaan pekerjaan itu nantinya dapat tercapai efesiensi dan efektifitas waktu serta biaya. [6]

2. Pengertian Pelelangan Terbuka dan Pelelangan Terbatas.

Pelelangan terbuka adalah pelelangan yang dilakukan secara terbuka untuk umum dengan pengumuman secara luas melalui media cetak dan papan pengumuman resmi untuk penerangan umum secara media elektronik.

Pelelangan terbatas adalah pelelangan yang dilaksanakan antar rekanan yang telah terdaftar dalam Daftar Rekanan Mampu yang mempunyai kualifikasi dan klafikasi budang tertentu sesuai dengan tingkat kebutuhan pada pelaksanaan pekerjaan.

\section{METODOLOGI PENELITIAN}

Kuisioner yang disebarkan kepada 43 kontraktor klasifikasi Klas B yang pernah atau sedang melaksanakan pekerjaan konstruksi di Propinsi Sumatera Barat yang tergabung dalam keanggotaan Gabungan Pengusaha Konstruksi Se-Indonesia (Gapensi).

Dari studi literatur dan pengumpulan data awal maka didapat beberapa kriteria dalam teknik penilaian pemenang tender yang dapat dijadikan pedoman dalam penyusunan kuesioner untuk pelaksanaan tender dalam Proyek Konstruksi sesuai Keppres 80 tahun 2003 [2] adalah sebagai berikut :

a. Kriteria penilaian pemenang berdasarkan penawaran harga terendah.

b. Kriteria penilaian pemenang berdasarkan kelengkapan syarat rakualifikasi, yang meliputi :

- Penawaran Harga Terendah.

- Metode Pelaksanaan.

- Keahlian atau Sumber Daya Manusia.

- Pengalaman Perusahaan.

- Neraca Keuangan Perusahaan.

- Peralatan Yang digunakan.

- Waktu Penyelesaian.

Kriteria-kriteria diatas merupakan unsur-unsur pokok yang perlu diperhatikan dalam menentukan pertanyaan Tentang Teknik Penilaian Pemenang Tender dalam Proyek Konstruksi.

\section{HASIL DAN PEMBAHASAN}

Persentase pengembalian kuesioner yang telah disebarkan kepada pihak-pihak yang telah direncanakan dapat dilihat pada Tabel 1.

Tabel 1. Jumlah Penyebaran Dan Pengembalian Kuesioner

\begin{tabular}{|c|c|c|}
\hline $\begin{array}{c}\text { Jumlah } \\
\text { Kuesioner } \\
\text { yang disebar }\end{array}$ & $\begin{array}{c}\text { Jumlah } \\
\text { Kuesioner } \\
\text { yang kembali }\end{array}$ & $\begin{array}{c}\text { Persentase } \\
\text { kuesioner } \\
\text { yang akan } \\
\text { diolah }\end{array}$ \\
\hline 50 & 43 & $86 \%$ \\
\hline
\end{tabular}

Dari Tabel 1 dapat dilihat persentase pengembalian kuesioner mencapai $86 \%$ (delapan puluh enam persen). Dalam penyebaran dan pengumpulan kuesioner tersebut terdapat beberapa kendala dilapangan, diantaranya adalah :

a. Responden yang dihadapi di bidang kontraktor ini merupakan orang yang pengambil keputusan di lapangan, sehingga mereka memerlukan cukup waktu untuk pengisian kuesioner.

b. Diperlukan adanya persetujuan dari pimpinan lembaga tersebut sebelum responden melakukan pengisian kuesioner karena adanya kekawatiran dari responden kalau jawaban yang mereka berikan akan mempengaruhi nama baik perusahaan.

Berikut ini akan diuraikan jawaban responden terhadap kuesioner yang disebarkan ke perusahaan-perusahaan kontraktor sebagai peserta pelaksanaan pekerjaan proyek :

1. Penilaian secara penawaran harga tentang kretaria tender, dapat dilihat sesuai jawaban kuisioner pada Tabel 2. 
Tabel 2. Penilaian Secara Penawaran harga Terendah

\begin{tabular}{lll}
\hline Indikator & $\begin{array}{c}\text { Jumlah } \\
\text { Perusahaan }\end{array}$ & $\begin{array}{l}\text { Persentase } \\
(\%)\end{array}$ \\
\hline $\begin{array}{l}\text { Sangat } \\
\text { Penting }\end{array}$ & 22 & $51 \%$ \\
\hline Penting & 17 & $39 \%$ \\
\hline $\begin{array}{l}\text { Kurang } \\
\text { Penting }\end{array}$ & 4 & $10 \%$ \\
\hline Total & 43 & $100 \%$ \\
\hline
\end{tabular}

2. Penilaian terhadap metode pelaksanaan untuk kretaria tender, dapat dilihat sesuai jawaban kuesioner pada Tabel 3.

Tabel 3. Penilaian Metode Pelaksanaan Sebagai Kritaria Tender

\begin{tabular}{lll}
\hline Indikator & $\begin{array}{l}\text { Jumlah } \\
\text { Perusahaan }\end{array}$ & $\begin{array}{l}\text { Persentase } \\
(\%)\end{array}$ \\
\hline $\begin{array}{l}\text { Sangat } \\
\text { Penting }\end{array}$ & 34 & $79 \%$ \\
\hline Penting & 9 & $21 \%$ \\
\hline $\begin{array}{l}\text { Kurang } \\
\text { Penting }\end{array}$ & 0 & $0 \%$ \\
\hline Total & 43 & $100 \%$ \\
\hline
\end{tabular}

3. Penilaian terhadap tenaga ahli untuk kretaria tender, dapat dilihat sesuai jawaban kuesioner pada Tabel 4.

Tabel 4. Penilaian Tenaga Ahli Sebagai Kretaria Tender

\begin{tabular}{lll}
\hline Indikator & $\begin{array}{l}\text { Jumlah } \\
\text { Perusahaan }\end{array}$ & $\begin{array}{l}\text { Persentase } \\
(\boldsymbol{\%})\end{array}$ \\
\hline Sangat Penting & 33 & $77 \%$ \\
\hline Penting & 10 & $23 \%$ \\
\hline Kurang Penting & 0 & $0 \%$ \\
\hline Total & 43 & $100 \%$ \\
\hline
\end{tabular}

4. Penilaian terhadap pengalaman perusahaan untuk kretaria tender, dapat dilihat sesuai jawaban kuesioner pada Tabel 5.

Tabel 5. Penilaian Terhadap Pengalaman Perusahaan Sebagai Kriteria Tender

\begin{tabular}{lll}
\hline Indikator & $\begin{array}{l}\text { Jumlah } \\
\text { Perusahaan }\end{array}$ & $\begin{array}{l}\text { Persentase } \\
(\boldsymbol{\%})\end{array}$ \\
\hline Sangat Penting & 18 & $42 \%$ \\
\hline
\end{tabular}

\begin{tabular}{lll}
\hline Penting & 20 & $45 \%$ \\
\hline Kurang Penting & 5 & $13 \%$ \\
\hline Total & 43 & $100 \%$ \\
\hline
\end{tabular}

5. Penilaian terhadap Modal Perusahaan untuk kretaria tender, dapat dilihat sesuai jawaban kuesioner pada Tabel 6.

Tabel 6. Penilaian Terhadap Kemampuan Keuangan Perusahaan Sebagai Kriteria Tender

\begin{tabular}{|l|l|l|}
\hline Indikator & $\begin{array}{l}\text { Jumlah } \\
\text { Perusahaan }\end{array}$ & $\begin{array}{l}\text { Persentase } \\
(\mathbf{\%})\end{array}$ \\
\hline Sangat Penting & 32 & $74 \%$ \\
\hline Penting & 11 & $26 \%$ \\
\hline Kurang Penting & 0 & $0 \%$ \\
\hline Total & 43 & $100 \%$ \\
\hline
\end{tabular}

6. Penilaian terhadap kelengkapan peralatan perusahaan untuk kretaria tender, dapat dilihat sesuai jawaban kuesioner pada Tabel 7.

Tabel 7. Penilaian Terhadap Kelengkapan Alat Sebagai Kriteria Tender

\begin{tabular}{|l|c|c|}
\hline \multicolumn{1}{|c|}{ Indikator } & $\begin{array}{c}\text { Jumlah } \\
\text { Perusahaan }\end{array}$ & \% Bobot \\
\hline Sangat Penting & 15 & $35 \%$ \\
\hline Penting & 20 & $47 \%$ \\
\hline Kurang Penting & 8 & $18 \%$ \\
\hline \multicolumn{1}{|c|}{ Total } & 43 & $100 \%$ \\
\hline
\end{tabular}

7. Penilaian terhadap waktu pelaksanaan sebagai kretaria tender, dapat dilihat sesuai jawaban questioner pada Tabel 8.

Tabel 8. Penilaian Waktu Pelaksanaan Sebagai Kretaria Tender

\begin{tabular}{|l|c|c|}
\hline \multicolumn{1}{|c|}{ Indikator } & $\begin{array}{c}\text { Jumlah } \\
\text { Perusahaan }\end{array}$ & \% Bobot \\
\hline Sangat Penting & 38 & $88 \%$ \\
\hline Penting & 5 & $12 \%$ \\
\hline Kurang Penting & 0 & $0 \%$ \\
\hline \multicolumn{1}{|c|}{ Total } & 43 & $100 \%$ \\
\hline
\end{tabular}

Grafik besarnya jawaban responden diatas dapat dilihat pada Gambar 2 . Permodelan ini akan dilakukan berdasarkan persentase bobot terbesar yang didapat pada kriteria penilaian untuk pengevaluasi pemenang tender. Nilai bobot diambil berdasarkan persentase jumlah jawaban terbesar yang 
didapat dari kuesioner yang telah disebar sesuai Tabel 9.

Tabel 9. Persentase Bobot Untuk Pemodelan

\begin{tabular}{|c|c|c|c|c|c|}
\hline \multirow[t]{2}{*}{ No } & \multirow{2}{*}{$\begin{array}{l}\text { Kriteria } \\
\text { Penilaian }\end{array}$} & \multicolumn{3}{|c|}{ Indikator } & \multirow[t]{2}{*}{$\%$} \\
\hline & & SP & $\mathbf{P}$ & TP & \\
\hline \multirow[t]{2}{*}{1} & Penawaran & 22 & - & - & $11 \%$ \\
\hline & Terendah & & & & \\
\hline \multirow[t]{2}{*}{2} & Metode & 34 & - & - & $17 \%$ \\
\hline & Pelaksanaan & & & & \\
\hline 3 & Tenaga Ahli & 33 & - & - & $17 \%$ \\
\hline \multirow[t]{2}{*}{4} & Pengalaman & - & 20 & - & $10 \%$ \\
\hline & Perusahaan & & & & \\
\hline \multirow[t]{2}{*}{5} & Modal & 32 & - & - & $16 \%$ \\
\hline & Perusahaan & & & & \\
\hline \multirow[t]{2}{*}{6} & Sumber Daya & - & 20 & - & $10 \%$ \\
\hline & Peralatan & & & & \\
\hline \multirow[t]{6}{*}{7} & Waktu & 38 & - & - & $19 \%$ \\
\hline & Penyelesaian & & & & \\
\hline & Total & 159 & 40 & & \\
\hline & Jawaban & & & & \\
\hline & Bobot & $79 \%$ & $21 \%$ & & $100 \%$ \\
\hline & Tertinggi & & & & \\
\hline
\end{tabular}

Dari Tabel 9 dapat dilihat bahwasanya Waktu pelaksanaan merupakan bobot terbesar yaitu $19 \%$ dari 7 (tujuh) kriteria yang dianggap sangat penting oleh responden. Hal ini disebabkan karena waktu pelaksanaan secara garis besar mamberikan dampak terhadap kinerja dan biaya pekerjaan yang akan dilaksanakan.

Sementara Metode Pelaksanaan dan Tenaga Ahli memperoleh bobot sebesar 17\% terbesar kedua yang dianggap sangat penting oleh responden. Hal ini disebabkan karena lancarnya suatu pekerjaan dipengaruhi oleh metode dan tenaga ahli yang sesuai dengan pekerjaan yang akan dikerjakan.

Untuk modal perusahaan dengan bobot sebesar $16 \%$ merupakan bobot terbesar ketiga dari jawaban respoden menyetujui kriteria penilaian ini. Selanjutnya Penawaran harga terendah memiliki bobot sebesar $11 \%$ yang dianggap penting karena untuk menentukan biaya yang di tawarkan tidak melebihi dana yang telah disediakan oleh pemberi kerja (Owner).

Dan bobot terakhir yang dianggap sangat penting oleh responden sebesar 10\% adalah Peralatan kerja dan Pengalaman Perusahaan. Hal ini disebabkan karena suatu perusahaan konstruksi jika memiliki peralatan (tools) dan alat berat (equipment) yang lengkap maka akan menjadi suatu nilai tambah untuk menunjang pekerjaan yang akan dikerjakan dan pemilik proyek (owner) tidak perlu meragukan pelaksanaan pekerjaan jika terjadi kendala yang disebabkan oleh ketidak tersediaan peralatan. Pekerjaan mobilisasi alat ini adalah pekerjaan awal yang harus dilaksanakan pada proyek konstruksi, apabila mengalami keterlambatan maka secara otomatis rangkaian kegiatan tersebut juga akan mengalami kemunduran dan sebaliknya.

Untuk Pengalaman perusahaan di nilai penting karena dari pengalaman perusahaan inilah dapat dilihat kemampuan perusahaan dalam setiap tahunnya dalam mendapatkan dan menyelesaikan suatu proyek. Dan secara otomatis akan dapat dinilai apakah suatu perusahaan memiliki struktur organisasi yang kuat dalam menyelesaikan setiap pekerjaan dan panitia lelang akan mempunyai suatu pertimbangan lebih untuk penawaran yang akan diajukan perusahaan tersebut karena hal yang disebutkan diatas.

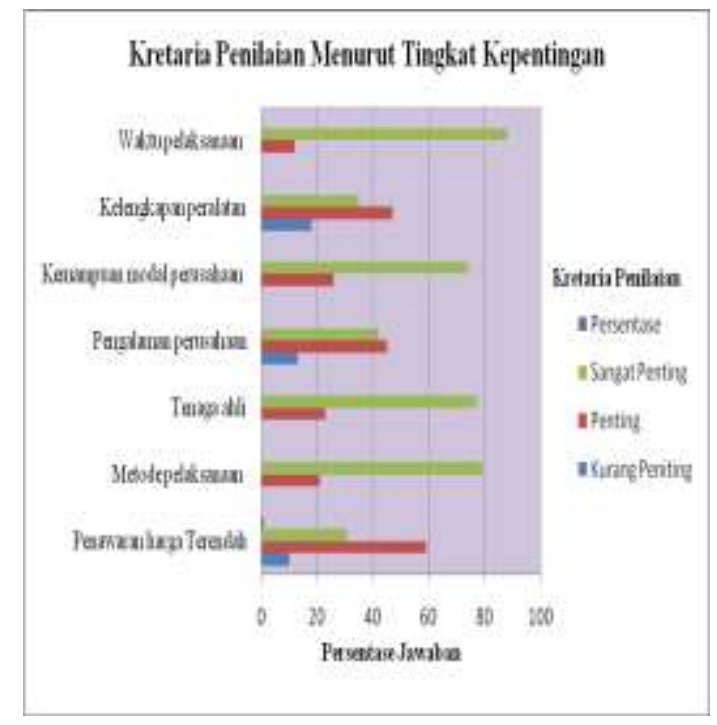

Gambar 2. Kriteria Penilaian Menurut Tingkat Kepentingan 


\section{KESIMPULAN DAN SARAN 5.1 Kesimpulan}

Dari analisis untuk kriteria penilaian dalam mencari pemenang tender yang dilakukan maka dapat diambil kesimpulan sebagai berikut :

1. Kriteria penilaian yang perlu diperhatikan untuk mencari pemenang tender berdasarkan urutan bobot penilaian adalah :
a. Waktu Pelaksanaan
$19 \%$
b. Metode Pelaksanaan
$17 \%$
c. Tenaga Ahli
$17 \%$
d. Modal Perusahaan
$16 \%$
e. Penawaran Harga
$11 \%$
f. Sumber Daya Peralatan
$10 \%$
g. Pengalaman Perusahaan
$10 \%$

2. Pengaruh dari masing-masing penilaian :

a. Waktu penyelesaian : waktu penyelesaian sangat diperlukan dalam proses konstruksi dan akan dimasukan dalam dokumen kontrak, semakin cepat waktunya maka semakin cepat pula proyek dapat digunakan sementara bagi perusahaan disamping mendapat keuntungan akan dapat pula merencanakan pekerjaan lainnya.

b. Metode pelaksanaan : merupakan penjabaran dari tata cara dan teknik-teknik pelaksana pekerjaan. Metode pelaksanaan mempunyai keterkaitan antara persyaratan dalam dokumen lelang (harga penawaran) keadaan teknis dan ekonomis dilapangan dan seluruh sumber daya termasuk pengalaman kontraktor. Keterkaitan 3 elemen ini akan membentuk kerangka gagasan dan konsep metoda optimal yang diterapkan oleh pelaksana konstruksi.

c. Tenaga Ahli : semakin tinggi kemampuan dan banyak tenaga ahli yang dimiliki oleh suatu perusahaan maka akan berdampak terhadap penyelesaian pekerjaan dan semakin besar peluang perusahaan tersebut untuk memenangkan tender.

d. Modal Perusahaan : modal perusahaan memegang pranan penting dalam dunia industri konstruksi karena disini perusahaan dapat membuat cash flow terhadap pekerjaan yang akan dilaksanakan, dengan kemampuan modal yang kuat akan mudah merencanakan proses pengadaan untuk pekerja, peralatan maupun material.

e. Sumber Daya Peralatan : merupakan nilai tambah untuk memenangkan tender karena ketersediaan peralatan akan mempengaruhi cepat atau lambatnya suatu proyek konstruksi dimulai atau diselesaikan, dan hal ini akan memberikan nilai tambah bagi perusahan yang akan memenangkan tender.

f. Pengalaman perusahaan : apabila suatu perusahaan mempunyai pengalaman perusahaan (pengalaman kerja perusahaan) yang tinggi maka pihak panitia lelang akan mempunyai suatu pertimbangan lebih untuk penawaran yang akan diajukan perusahaan tersebut.

\subsection{Saran}

Panitia tender dalam pemilihan pemenang tender benar-benar memperhatikan 7 (tujuh) kriteria-krieria teknik penilaian dari perusahaan peserta tender disamping penawaran harga yang terendah. Karena disamping penawaran terendah, faktor persyaratan prakulifikasi tersebut diatas sangat penting untuk dipertimbangkan dan dijadikan dasar menentukan besarnya nilai pembobotan dalam menilai masing-masing kretaria proses pemilihan.

\section{DAFTAR PUSTAKA}

[1] Dipohusodo, I. 1996. Manajemem Proyek dan Konstruksi, Jilid 1, Kanisius, Yogyakarta.

[2] Keputusan Presiden Republik Indonesia Nomor 80 Tahun 2003 Tentang Pedoman Pelaksanaan Pengadaan Barang/Jasa Pemerintah.

[3] Donald S. Barrie. 1992, Professional Construction Management ( $3^{\text {rd }}$ Edition), Publisher: McGraw-Hill Publishing Company.

[4] Suharto, Imam: Manajemen Proyek (Dari konseptual sampai Operasional), Penerbit, Airlangga, edisi kedua, 2016.

[5] Ervianto, Wulfram I Manajemen proyek konstruksi / Wulfram I. Ervianto, Penerbit: Andi, Yogyakarta, 2007.

[6] Kuncoro, Agus, S.Sos,S.E., Ak. 2011. Cara Benar Menang Tender Pengadaan Barang/Jasa Pemerintah (PerPres Nomor 54 tahun 2010). Kawah Media. Jakarta. 